\title{
The Use of Indicators in Modified Historical Model to Estimate the Intrinsic Value of a Stock
}

\section{Gottwald Radim}

\begin{abstract}
The article mentions several methods of a fundamental analysis used to value stocks. It primarily focuses on the historical model. This model enables undervalued, correctly valued and overvalued stocks to be identified. The model is further modified in the article, using selected accounting indicators. The modified model versions are applied to selected stocks in the SPAD segment, Prague Stock Exchange, within the 2005-2010 period. Empirical analysis is applied to a comparison of accuracy of the accounting indicator value estimates and accuracy of stock intrinsic value estimates, both separately for each stock and accounting indicator. The comparisons of accuracy of the accounting indicator value estimates and the accuracy of the stock intrinsic value estimates are also done based on the length of applied time period. With respect to the obvious fierce competition between stock issuers within the financial markets, the model enables potential investors, who are to select from an extensive offer of stocks, to make better informed investment decisions.
\end{abstract}

Key words: historical model, intrinsic value of a stock, stock valuation

\section{INTRODUCTION}

There are many types of securities traded on the financial markets. To value the securities, various types of investment analyses including fundamental analysis have been defined. Focusing on the historical model of the fundamental analysis, author applies modified versions of this model to real data. That is the main goal of the article. Concretely, the versions are applied to selected stocks in the SPAD segment, Prague Stock Exchange. The accounting indicator value estimates and the stock intrinsic value estimates are compared, too. Presented model enables potential investors, who are to select from actual extensive offer of stocks, to make better informed investment decisions.

\section{LITERARY SURVEY}

According to Veselá (2003), the historical model method is seen as a suitable auxiliary tool to methods respecting the time value of money. Brown and Reilly (2009) mention not only the principle of the historical model, but also possible situations in practice, under which this model can be used. Indicators used in historical model like price to sales, price to book and other are described by Little (2012). These indicators are often signed as price multiples. Historical model is, similarly like other models, sometimes used in empirical analyses to estimate the intrinsic value of a stock. Analyzing stocks from the Warsaw Stock Exchange in the period 1999-2008, Welc (2010) uses historical model. Using price to sales indicator, he creates portfolios based upon undervaluation and overvaluation. The comparison of annual and total return 
on the portfolios and annual and total return on the Warsaw Stock Exchange index is added, too. Determinating the Goldman Sachs stocks intrinsic value, Yao (2004) compares the historical model with the residual income model and the dividend discount model. He uses price to sales indicator, price to book indicator and price to earnings indicator. On the other hand, this article uses the data of stocks traded on the Prague Stock Exchange and the contribution of this article consists in measuring of the accuracy of the accounting indicator value estimates and the accuracy of the stock intrinsic value estimates.

The article is structured as follows: Chapter 1 focuses on the fundamental analysis. Author presents benefits and parts of this analysis. Various ways how to determine the intrinsic value of a stock are analysed, too. Author exactly defines objective and used methodology in Chapter 2. Complete empirical analysis related to selected stocks from the Prague Stock Exchange is described in Chapter 3. Author comments and discusses about the founded results in Chapter 4. Significant findings about determining the intrinsic value of a stock are concluded in Chapter 5.

\subsection{Benefits of the Fundamental Analysis}

The results of the fundamental analysis are beneficial for a number of individuals, namely financial analysts, investors, stockholders, brokers and others. These people continuously monitor the company's financial results, e.g. whether any profit is being generated or if dividends are being paid out, or what economic development will be shown in the long run. In addition, they are interested in the liquidity of the individual issues of securities. The sources of necessary data include, in particular, various financial statements of a company, such as balance sheet, profit and loss account and cash flow statement. Brickner, Brown and Myring (2007) analyse the benefit of fundamental analysis to the clarification of unexpected market behaviour. The market participants track various signals resulting from the fundamental analysis in order to clarify company revenues, both for the companies generating profit and companies in loss. Elleuch (2009) studies the possibility to predict stock revenues via fundamental analysis based on historical accounting data. By applying the respective methodology, he classifies the stocks as stock with positive and negative revenue, which results in a more favourable distribution of stock revenues for investors in the future. The research results point out a significant positive correlation between certain indicators resulting from the fundamental analysis and stock revenues in the future.

\subsection{Parts of a Fundamental Analysis}

In general, the fundamental analysis may be divided into three parts, i.e. macroeconomic analysis, industry analysis and analysis of the individual companies. The macroeconomic analysis assesses the respective economy in general and describes the influence of the individual factors on the prices of securities. There are a number of factors affecting the business of the economic entities, such as real output of the economy (measured, for example, with GDP), money supply level (using monetary aggregates), interest rate level (using the discount, repo and lombard rate) and inflation (using the inflation rate), government fiscal policy (using the public debt) and other factors. The indicators used in the macroeconomic analysis are available in the databases of statistical offices, ministries and other government or private institutions. The industry analysis assesses a specific industry. The individual industries may differ, for example, 
in the number of competing companies, conditions of entry, type of structure (monopoly, perfect competition, oligopoly, etc.), life cycle, sensitivity to economic cycle (cyclic, anti-cyclic and neutral industries), degree of public regulation and supervision, average generated profit, export opportunities, etc.

The analysis of the individual companies assesses the important economic indicators of the monitored companies. This analysis may be qualitative or quantitative. The qualitative analysis may be carried out as, for example, SWOT analysis or PESTE analysis. The quantitative analysis examines the development of ratio indicators and the horizontal, or vertical analysis. The ratio indicators are compared using spatial analysis, trend analysis, comparison against the plan and comparison based on expert experience. There are two possible fundamental analysis methods. The method "top down" first carries out the macroeconomic analysis, then the industry analysis followed by analysis of the individual companies. The "bottom up" approach follows the reverse order.

\subsection{Determining the Intrinsic Value of a Stock}

In order to determine undervalued, correctly valued and overvalued stocks the intrinsic values of stocks calculated using a certain model are compared with the current market price of a stock. Based on this calculation, an investment decision is put forward, recommending buying or selling the stock. Many underpriced and overpriced stocks are on the markets. The intrinsic value of a stock is the price reflecting the actual value of the stock. While the price of a stock fluctuates even within a very short period of time, the intrinsic value of a stock is considered fixed within a very short period of time. Zhong, Darrat and Anderson (2003) assess the degree to which the prices of American stocks deviate from their intrinsic values. They further examine whether the method of present value should also, in order to obtain a more accurate current price of a stock, include the expected inflation varying over time.

There are several models that can be used to determine an intrinsic value of a stock. In addition to the historical model, they include the dividend discount model, profit model and other models. The dividend discount model is based on an assumption that the intrinsic value of a stock equals the present value of future dividends generated by this stock. In general, the dividend growth may be, over time, zero, constant or variable, or the company may not pay out any dividends. Gottwald (2011) notes that investors can estimate the expected dividend growth rate based on the historical data analysis, subjective estimates of financial analysts or financial indicators of the respective company. Applying the profit model, the P/E (price/earnings ratio) is used, which is a ratio of the current price of a stock to the current net profit of the company per one stock. The $\mathrm{P} / \mathrm{E}$ ratio is primarily affected by the dividend policy, the quality of company management, type of industry and its popularity amongst investors and used accounting method. Chisholm (2009) studies the issues related to the application of the $\mathrm{P} / \mathrm{E}$ ratio in practice. He elicits various differences in used accounting methods of pricing, problems with determining the average $\mathrm{P} / \mathrm{E}$ for stocks of companies from different industries and limited explanatory power of $\mathrm{P} / \mathrm{E}$ for companies not generating a profit but a loss. There are also other models applied in practice. Halsey (2000) interprets the breakdown of DuPont net income by the residual income model, which subsequently applies to the Nordstrom stock. Mingzhe (2008) describes a model of extraordinary revenues continuous in time, which does 
not embrace some of the disadvantages of the dividend discount model and the discounted cash flow model. The thing is that for these two models it is necessary to estimate the expected future values of accounting variables. Through a generating function of the accounting variables, these variables are transformed into such a form that it is easier to estimate. The model of extraordinary revenues continuous in time is further applied to the Chinese stock market stock. A model that is based on accounting information is described by Thompson, Beatty and Riffe (2001). They set conditions under which, if complied with, the log-linear regression used in the model provides estimates with a minimum deviation. To assess the suitability of data to be used in the model, specific tests are proposed below and the model is applied to selected stocks.

\section{OBJECTIVE AND METHODOLOGY}

The article primarily focuses on the modification of the historical model using selected accounting indicators. The modified versions of the historical model are further applied to real data as a part of the empirical analysis. That is the objective of this article.

The comparison of accuracy of the accounting indicator value estimates and accuracy of the stock intrinsic value estimates, separately for each stock and each accounting indicator, is realized. It is accomplished by comparing the expected accounting indicator value obtained through linear regression with the actual accounting indicator value in the same period, both separately for each stock and each accounting indicator, as well as by comparing the calculated stock intrinsic value with the average price of a stock within the same period, both separately for each stock and each accounting indicator.

The comparison the accuracy of the accounting indicator value estimates and accuracy of the stock intrinsic value estimates based on the length of the respective time period, is realized, too. This is accomplished by comparing the expected value with the actual value and, simultaneously, comparing the intrinsic value with the average price, for one selected stock and one selected accounting indicator.

The advantage of the method is that it is derived from other method of fundamental analysis, which is often used by many investors in practice. There is no problem to apply the method to selected market. The needed data are usually available. The difference between actual and expected value of accounting indicator denotes how much exact is the method. On the other hand, estimating of the intrinsic value is influenced by volatility of used indicators. That could be problematic in some cases. Negative market trends within financial crisis cause limits of use of historical models, in general. The behaviour and expectation of subjects on financial market during crisis differ from previous ones during economic stability. As a consequence of financial crisis after 2008, behaviour of joint-stock companies and investors has changed. To find an intrinsic value of a stock, investors use at once more methods than before. To find whether some stock is undervalued or overvalued during strong market instability, the alternative to use models based on different principles is better for investors.

The article applies methods designed to determine the intrinsic value of a stock with a historical model. Based on the time series analysis statistical method, linear regression is used to determine the expected values of the selected accounting indicators. Using the least square method the historical values are approximated by the linear function, based on which the 
expected value is calculated. Concretely, probable value of certain accounting indicator in the future is calculated via linear regression. The $\mathrm{a}$ and $\mathrm{b}$ parameters of the functional dependency of the z:

$f(z)=a \cdot z+b$

are calculated as the:

$$
\begin{aligned}
& a=\frac{n \cdot \sum_{i=1}^{n} x_{i} \cdot y_{i}-\sum_{i=1}^{n} x_{i} \cdot \sum_{i=1}^{n} y_{i}}{n \cdot \sum_{i=1}^{n} x_{i}^{2}-\left(\sum_{i=1}^{n} x_{i}\right)^{2}} \\
& b=\frac{\sum_{i=1}^{n} x_{i}^{2} \cdot \sum_{i=1}^{n} y_{i}-\sum_{i=1}^{n} x_{i} \cdot \sum_{i=1}^{n} x_{i} \cdot y_{i}}{n \cdot \sum_{i=1}^{n} x_{i}^{2}-\left(\sum_{i=1}^{n} x_{i}\right)^{2}}
\end{aligned}
$$

whereas $a$ and $b$ are values of the parameter in functional dependency, $n$ expresses the number of input values, while specific values are signed as $x_{i}$ and $y_{i}$. The values yi here represent historical values of selected accounting indicators and values $x_{i}$ represent the numerical series 1 , 2,3 to $n$. Since these values are compared with the actual values within the same period, the year 2010 was selected as the respective period taking into account the availability of necessary data.

The historical model generally uses the comparison of the average price of a stock over a certain period of time with another average historical value over the same period, especially with the average amount of dividends ( $\mathrm{P} / \mathrm{D}$ historical model) or average book value of a company (P/BV historical model). The principle of the historical model is clearly demonstrated by the general formula of the historical model calculating the intrinsic value of a stock:

$V=\frac{P}{A} \cdot A_{1}$

whereas $\mathrm{V}$ is intrinsic value of a stock and $P$ is average price of a stock for a certain period. The average amount of the certain accounting indicator for the same period is signed as $A$, while amount of the certain accounting indicator for the following period is signed as $A_{1}$. Thus, $A_{1}$ is the expected amount. In other words, it is probable value of certain accounting indicator, which is calculated for the following period via linear regression. The intrinsic value $V$ relates to the following period. In practice, the accounting indicators usually include the dividends or book value of the company. The modification of the historical model concerns the replacement of these two accounting indicators with other indicators. These indicators characterize the results of companies from economic point of view.

\section{RESULTS}

The empirical analysis uses the data of stocks traded on the Prague Stock Exchange. The segment SPAD trades the most prestigious stock offered by the stock exchange. Out of this seg- 
ment, considering the availability of the necessary data, there are five stocks selected that are subject to the empirical analysis. The data cover the period between 2005 and 2010. These data are sourced from the Patria Finance, a.s. database. Thus via Patria Online, a.s. (2012) it was possible to obtain all necessary input data for the empirical analysis, especially historical prices of stocks and values of accounting indicators.

The historical model is modified step-by-step for three accounting indicators, i.e. profit, assets and sales. More specifically, for net profit presented in the profit and loss account, total assets presented in the balance sheet and sales presented in the profit and loss account. These indicators are one by one added to the general formula of the historical model as variable A, resp. A1. These three indicators belong among often used indicators in stock analysis. Meluzín and Zinecker (2011) use sales of several companies and they note a significant increase in sales in the pre-IPO period and a subsequent significant decrease in the post-IPO period.

Data (except for average prices and intrinsic values in EUR) of these companies are always stated in EUR millions:

- AAA,

- PEGAS NONWOVENS.

Data (except for average prices and intrinsic values in CZK) of these companies are always stated in CZK millions:

- $\check{C} \mathrm{EZ}$,

- PHILIP MORRIS ČR,

- TELEFÓNICA C.R.

Data are stated in one of the currencies in financial statements related always to one of chosen years. To obtain approximate recalculated value in other currency, the exchange rate to March of following year must be used. For a stock of each company and for each of the three accounting indicators used the necessary data are gradually collected. Firstly, profit, assets and sales of the company for 2005, 2006, 2007, 2008 and 2009 are determined. Via the linear regression the expected value for 2010 is calculated. The actual value for 2010 is also collected. Thus it is possible to compare the expected values of profit, assets and sales obtained through the linear regression with the actual profit, assets and sales in 2010, separately for each stock. Table 1 presents a comparison of accuracy of profit estimates of selected companies for 2010, separately for each stock.

Tab. 1 - Comparison of Accuracy of Profit Estimates. Source: Patria Online (2012) and own calculations

\begin{tabular}{|c|c|c|c|}
\hline Company & Expected Profit & Actual Profit & Profits Ratio \\
\hline AAA & -19 & 5 & $-3,76$ \\
\hline ČEZ & 68029 & 52884 & 1,29 \\
\hline PEGAS NONWOVENS & 27 & 21 & 1,29 \\
\hline PHILIP MORRIS ČR & 1960 & 2389 & 0,82 \\
\hline TELEFÓNICA C.R. & 13922 & 12280 & 1,13 \\
\hline
\end{tabular}


Profit belongs among such accounting indicators, which can be positive or negative, in general. Sometimes could happen, that investors expect positive profit, but the company will realize loss. The accuracy of asset estimates of selected companies for 2010, separately for each stock is also compared. It is shown in Table 2.

Tab. 2 - Comparison of Accuracy of Asset Estimates. Source: Patria Online (2012) and own calculations

\begin{tabular}{|c|c|c|c|}
\hline Company & Expected Assets & Actual Assets & Assets Ratio \\
\hline AAA & 103 & 81 & 1,27 \\
\hline ČEZ & 568434 & 543691 & 1,05 \\
\hline PEGAS NONWOVENS & 240 & 251 & 0,96 \\
\hline PHILIP MORRIS ČR & 13917 & 15741 & 0,88 \\
\hline TELEFÓNICA C.R. & 87285 & 92792 & 0,94 \\
\hline
\end{tabular}

The ratios in this table tend more to 1,00 than in previous table, in general. Similarly, the comparison of accuracy of sales estimates of selected companies for 2010, separately for each stock is illustrated in Table 3.

Tab. 3 - Comparison of Accuracy of Sales Estimates. Source: Patria Online (2012) and own calculations

\begin{tabular}{|c|c|c|c|}
\hline Company & Expected Sales & Actual Sales & Sales Ratio \\
\hline AAA & 210 & 205 & 1,02 \\
\hline ČEZ & 219027 & 198848 & 1,10 \\
\hline PEGAS NONWOVENS & 180 & 148 & 1,22 \\
\hline PHILIP MORRIS ČR & 10597 & 11402 & 0,93 \\
\hline TELEFÓNICA C.R. & 62362 & 55712 & 1,12 \\
\hline
\end{tabular}

Based on the presented ratios of expected and actual profit, assets and sales it is clear that, while for $\check{C} E Z$ the values of expected accounting indicators are always above the actual values of accounting indicators, for PHILIP MORRIS ČR they are always below. The ratio of expected and actual accounting indicators varies between $-3,76$ and 1,29. It is possible to find the rate how much are values determined through the linear regression overvalued compared to the actual values. They are overvalued by max. $29 \%$.

Furthermore, the average price of a stock for 2005-2009 is determined, which is an arithmetic average of daily closing prices of a stock during the respective period, and average profit, assets and sales for 2005-2009, which is calculated as the arithmetic average of profit, assets and sales for 2005, 2006, 2007, 2008 and 2009. Using the expected profit, assets and sales presented above in Table 1, Table 2 and Table 3 and the general formula of the historical model, the intrinsic value of a stock for 2010 is calculated. It is thus possible to compare the calculated intrinsic value of a stock with the average price of a stock in 2010, separately for each stock 
and profit, assets and sales. The average price of a stock in 2010 is calculated as an arithmetic average of daily closing prices of a stock during 2010. The comparison of accuracy of stock intrinsic value estimates of selected companies, using the profit data, separately for each stock is presented in Table 4.

Tab. 4 - Comparison of Accuracy of Stock Intrinsic Value Estimates using the Profit Data. Source: Patria Online (2012) and own calculations

\begin{tabular}{|c|c|c|c|c|c|c|}
\hline Company & $\begin{array}{c}\text { Aver- } \\
\text { age Price } \\
(2005- \\
2009)\end{array}$ & $\begin{array}{c}\text { Average } \\
\text { Profit } \\
(2005- \\
2009)\end{array}$ & $\begin{array}{c}\text { Expected } \\
\text { Profit } \\
(2010)\end{array}$ & $\begin{array}{c}\text { Intrinsic } \\
\text { Value } \\
(2010)\end{array}$ & $\begin{array}{c}\text { Aver- } \\
\text { age } \\
\text { Price } \\
(2010)\end{array}$ & $\begin{array}{c}\text { Intrinsic } \\
\text { Value and } \\
\text { Price Ratio } \\
(2010)\end{array}$ \\
\hline AAA & 19 & -6 & -19 & 64 & 17 & 3,75 \\
\hline ČEZ & 880 & 38367 & 68029 & 1560 & 859 & 1,82 \\
\hline $\begin{array}{c}\text { PEGAS } \\
\text { NONWO- } \\
\text { VENS }\end{array}$ & 514 & 15 & 27 & 905 & 440 & 2,06 \\
\hline $\begin{array}{c}\text { PHILIP } \\
\text { MORRIS ČR }\end{array}$ & 10914 & 2161 & 1960 & 9896 & 9387 & 1,05 \\
\hline $\begin{array}{c}\text { TELEFÓNI- } \\
\text { CA C.R. }\end{array}$ & 483 & 9590 & 13922 & 701 & 418 & 1,68 \\
\hline
\end{tabular}

Based on the presented ratios of intrinsic value and price, the differences between calculated and real market values can be analysed. It is evident that, for all the companies, the intrinsic value is higher than the average price. With respect to the application of profit in determining the intrinsic value, these stocks are undervalued. Accuracy of stock intrinsic value estimates of selected companies using the asset data, separately for each stock is compared, too. Table 5 shows this comparison. 
Tab. 5 - Comparison of Accuracy of Stock Intrinsic Value Estimates using the Asset Data. Source: Patria Online (2012) and own calculations

\begin{tabular}{|c|c|c|c|c|c|c|}
\hline Company & $\begin{array}{c}\text { Aver- } \\
\text { age Price } \\
(2005- \\
2009)\end{array}$ & $\begin{array}{c}\text { Average } \\
\text { Assets } \\
(2005- \\
2009)\end{array}$ & $\begin{array}{c}\text { Expected } \\
\text { Assets } \\
(2010)\end{array}$ & $\begin{array}{c}\text { Intrinsic } \\
\text { Value } \\
(2010)\end{array}$ & $\begin{array}{c}\text { Aver- } \\
\text { age Price } \\
(2010)\end{array}$ & $\begin{array}{c}\text { Intrinsic } \\
\text { Value and } \\
\text { Price Ratio } \\
(2010)\end{array}$ \\
\hline AAA & 19 & 99 & 103 & 20 & 17 & 1,17 \\
\hline ČEZ & 880 & 413448 & 568434 & 1210 & 859 & 1,41 \\
\hline $\begin{array}{c}\text { PEGAS } \\
\text { NONWO- } \\
\text { VENS }\end{array}$ & 514 & 250 & 240 & 494 & 440 & 1,12 \\
\hline $\begin{array}{c}\text { PHILIP } \\
\text { MORRIS } \\
\text { ČR }\end{array}$ & 10914 & 15434 & 13917 & 9841 & 9387 & 1,05 \\
\hline $\begin{array}{c}\text { TELE- } \\
\text { FÓNICA } \\
\text { C.R. }\end{array}$ & 483 & 110364 & 87285 & 382 & 418 & 0,91 \\
\hline
\end{tabular}

Comparing the ratios of intrinsic value and price it is clear that for TELEFÓNICA C.R. the intrinsic value is lower than the average price. For all other companies the situation is to the contrary. Respecting the application of assets in determining the intrinsic value, these stocks, except for TELEFÓNICA C.R. stocks, are undervalued. The comparison of accuracy of stock intrinsic value estimates of selected companies, using the sales data, separately for each stock is realized in Table 6 .

Tab. 6 - Comparison of Accuracy of Stock Intrinsic Value Estimates using the Sales Data. Source: Patria Online (2012) and own calculations

\begin{tabular}{|c|c|c|c|c|c|c|}
\hline Company & $\begin{array}{c}\text { Aver- } \\
\text { age Price } \\
(2005- \\
2009)\end{array}$ & $\begin{array}{c}\text { Aver- } \\
\text { age Sales } \\
(2005- \\
2009)\end{array}$ & $\begin{array}{c}\text { Expected } \\
\text { Sales } \\
(2010)\end{array}$ & $\begin{array}{c}\text { Intrinsic } \\
\text { Value } \\
(2010)\end{array}$ & $\begin{array}{c}\text { Aver- } \\
\text { age Price } \\
(2010)\end{array}$ & $\begin{array}{c}\text { Intrinsic } \\
\text { Value and } \\
\text { Price Ratio } \\
(2010)\end{array}$ \\
\hline AAA & 19 & 287 & 210 & 14 & 17 & 0,82 \\
\hline ČEZ & 880 & 165818 & 219027 & 1162 & 859 & 1,35 \\
\hline $\begin{array}{c}\text { PEGAS } \\
\text { NONWO- } \\
\text { VENS }\end{array}$ & 514 & 103 & 180 & 900 & 440 & 2,05 \\
\hline $\begin{array}{c}\text { PHILIP } \\
\text { MORRIS } \\
\text { ČR }\end{array}$ & 10914 & 10796 & 10597 & 10713 & 9387 & 1,14 \\
\hline $\begin{array}{c}\text { TELE- } \\
\text { FÓNICA } \\
\text { C.R. }\end{array}$ & 483 & 62020 & 62362 & 485 & 418 & 1,16 \\
\hline
\end{tabular}


Using of sales is different than using of profit also in such sense, that sales cannot be negative, but profit can be. Based on the presented ratios of intrinsic value and price it is clear that, for all companies except for AAA, the intrinsic value is always higher than the average price. It means that, with respect to the application of sales in determining the intrinsic value, these stocks are, except for AAA stocks, undervalued. So that, investors could expect the decrease of AAA stock price and increase of other stock prices in the future. The comparison of accuracy of estimates separately for each stock and each accounting indicator was completely realized. Subsequently, the comparison of accuracy of estimates based on the length of time period is realized now.

Several stocks have been analysed to this time. Now, the stock of PHILIP MORRIS ČR and the accounting indicator of profit are selected. Using the linear regression, various expected values of profit for 2010 are determined, based on the length of the respective time period. The least square method is used to approximate historical values by the linear function. This linear function is based on which the expected value is calculated. It is thus possible to compare different expected values of profit obtained via the linear regression with the actual profit for 2010, which was CZK 2,389 million. It is possible to compare of accuracy of PHILIP MORRIS ČR profit estimates based on the length of respective time period, as it is presented in Table 7.

Tab. 7 - Comparison of Accuracy of PHILIP MORRIS ČR Profit Estimates Based on the Length of Respective Time Period. Source: Patria Online (2012) and own calculations

\begin{tabular}{|c|c|c|c|c|}
\hline Indicator & $\begin{array}{c}\text { Linear Regres- } \\
\text { sion (2008- } \\
2009)\end{array}$ & $\begin{array}{c}\text { Linear Regres- } \\
\text { sion (2007- } \\
2009)\end{array}$ & $\begin{array}{c}\text { Linear Regres- } \\
\text { sion (2006- } \\
2009)\end{array}$ & $\begin{array}{c}\text { Linear } \\
\text { Regression } \\
(2005-2009)\end{array}$ \\
\hline $\begin{array}{c}\text { Expected Profit } \\
(2010)\end{array}$ & 3320 & 2593 & 2399 & 1960 \\
\hline $\begin{array}{c}\text { Expected Profit } \\
\text { and Actual Profit } \\
\text { Ratio (2010) }\end{array}$ & 1,39 & 1,09 & 1,00 & 0,82 \\
\hline
\end{tabular}

There can be deducted that the expected profit is, within each period, higher than the actual profit. The ratio of expected and actual profit varies between 1,00 and 1,39. Thus the values calculated based on the linear regression are, compared to the actual value, overestimated by max. $39 \%$. Since 2006, it stands that the shorter the time interval included in the linear regression, the bigger the difference between the expected and actual profit; and the more recent the respective period included in the linear regression, the less accurate the estimate. In addition, various average prices of PHILIP MORRIS ČR stocks and various average profit values are determined, based on the length of the respective time period. Using the expected values of profit presented in Table 7 and general formula of the historical model, the intrinsic value of a stock related to 2010 is calculated. It is thus possible to compare different intrinsic values of PHILIP MORRIS ČR stocks with the average price in 2010, which is CZK 9,387. Table 8 presents last comparison, concretely comparison of accuracy of PHILIP MORRIS ČR stock intrinsic value estimates, using profit data, based on the length of the respective time period. 
Tab. 8 - Comparison of Accuracy of PHILIP MORRIS ČR Stock Intrinsic Value Estimates using Profit Data Based on the Length of Respective Time Period. Source: Patria Online (2012) and own calculations

\begin{tabular}{|c|c|c|c|c|}
\hline Indicator & $\begin{array}{c}\text { Linear Regres- } \\
\text { sion (2008- } \\
2009)\end{array}$ & $\begin{array}{c}\text { Linear Regres- } \\
\text { sion (2007- } \\
2009)\end{array}$ & $\begin{array}{c}\text { Linear Regres- } \\
\text { sion (2006- } \\
2009)\end{array}$ & $\begin{array}{c}\text { Linear Regres- } \\
\text { sion (2005- } \\
2009)\end{array}$ \\
\hline Average Price & 6520 & 7705 & 9106 & 10914 \\
\hline Average Profit & 2099 & 2055 & 2018 & 2161 \\
\hline $\begin{array}{c}\text { Expected Profit } \\
\text { (2010) }\end{array}$ & 3320 & 2593 & 2399 & 1960 \\
\hline $\begin{array}{c}\text { Intrinsic Value } \\
\text { (2010) }\end{array}$ & 10313 & 9721 & 10825 & 9897 \\
\hline $\begin{array}{c}\text { Intrinsic Value } \\
\text { and Average } \\
\text { Profit Ratio } \\
\text { (2010) }\end{array}$ & 1,10 & 1,04 & 1,15 & 1,05 \\
\hline
\end{tabular}

Based on the presented ratios of intrinsic value and average price, it is clear the relation between the intrinsic values and average prices. Intrinsic values are, within each period, higher than the average prices. Respecting the application of profit in determining the intrinsic value, such stocks are undervalued stocks. The ratio of intrinsic value and average price varies between 1,04 and 1,15. This means that intrinsic values are, compared to the average prices, overvalued by at least $4 \%$ and max. by $15 \%$.

\section{DISCUSSION}

Based on results, the diversity of used stocks leads to various relations between intrinsic values and prices. The empirical analysis uses the data of stocks from various sectors. Despite many factors influence values of accounting indicators, it has sense to compare calculated ratios in tables and deduct interesting findings presented in conclusion. In general, using different accounting indicators within calculation leads to different intrinsic values. To suggest more objective investment recommendation, investors can use more accounting indicators. Taking into account the principle of the historical model, these results are similar to results of some cited analyses, mainly Yao (2004) and Welc (2010).

Further research in the respective area may be done under various approaches. The described method may be modified in various manners. It is possible to compare results of the historical model between stocks of companies active in different industries. A different number of used stocks as well as a different number of selected accounting indicators may be used. Different accounting indicators may be selected. Another question concerns the length of period for which the data are analysed. In general, the longer the period, the more values in a time series of selected parameters analysed and the more objective the results. Nevertheless, the shorter the period is, the more the specific events affect the prices of stocks. The accounting indicators 
for fiscal years may be replaced with midterm, quarterly or monthly indicators. There are other methods that could be used to identify overvalued, correctly valued or undervalued stocks as well as, analogically, overvalued, correctly valued or undervalued stock markets. Investors find overpriced and underpriced stocks. Under various time periods it is also possible to retrospectively measure the dependency between the calculated intrinsic values and actual prices of stocks and, simultaneously, compare the fluctuation of different accounting indicators used to calculate the stock intrinsic value.

In practice, the $\mathrm{P} / \mathrm{BV}$ indicator is used, measuring the price of a stock in relation to the book value of the company. By various empirical analyses, the existence of the so-called low $\mathrm{P} / \mathrm{BV}$ effect is studied; this effect concerns the purchase of stocks with low P/BV. Specifically, it is examined whether the rate of return of stocks in the portfolio containing stocks with the lowest $\mathrm{P} / \mathrm{BV}$ values is higher than the rate of return of stocks in the portfolio containing the stocks with the highest $\mathrm{P} / \mathrm{BV}$ values. An investment strategy of purchasing stocks with the lowest $\mathrm{P} / \mathrm{BV}$ values often, but not always, results in such a rate of return that exceeds the rate of return of stocks with the highest $\mathrm{P} / \mathrm{BV}$ values. Such an approach may actually result in such a rate of return that exceeds the rate of return of the stock index of the respective stock exchange. Within a certain period of time, the effect of low P/BV may be analysed not only in one market (e.g. one stock exchange) but also in several markets (e.g. European or American) and, additionally, it is possible to analyse the intensity of this effect over time. In addition to the described low P/BV effect, the subsequent research may, analogically, determine the existence of a low effect for an indicator replacing the company's BV in the analysis, for example either one used above in the empirical analysis.

The benefit of the historical model lies in the possibility to identify overvalued, correctly valued and undervalued stocks. If the price of a stock exceeds its intrinsic value, the stock is overvalued, and vice versa for the undervalued stock. The prerequisite of the fundamental analysis is the possibility to determine an intrinsic value of every stock in order to see whether the stock is undervalued, correctly valued or overvalued. A number of entities in the financial markets study the intrinsic values of stocks applying a variety of methods. These entities primarily include investors, investment advisors, brokers, financial analysts, dealers and stockholders. Many investors choose their investment strategy based on results of the fundamental analysis, which allows them to take a number of factors into account when making an investment. Thus, their investment decision-making process may be simplified. The methods of fundamental analysis mentioned above thus, in general, allow for closer identification of a specific market and provide useful financial analytical instruments.

\section{CONCLUSION}

The article firstly describes the benefit of the fundamental analysis to the evaluation of stocks. In addition to defining the two objectives of the fundamental analysis, its parts are described, namely the macroeconomic analysis, industry analysis and analysis of the individual companies. Based on the results of the fundamental analysis it is possible to define an investment recommendation to the respective stock. In practice, several models determining the intrinsic value of a stock are used. The article mentions the dividend discount model, profit model, as 
well as others. The article focuses primarily on the historical model that compares the average price of a stock over a certain period of time with another average historical value over the same period of time. This model is modified using selected accounting indicators, namely profit, assets and sales. The data used have been collected from the Prague Stock Exchange. For the 2005-2010 period, the analysis compares the accuracy of stock intrinsic value estimates and accuracy of accounting indicator estimates, separately for each stock and each accounting indicator, i.e. profit, assets and sales. Additionally, the accuracy of the PHILIP MORRIS ČR stock intrinsic value estimates and accuracy of the profit value estimates, based on the length of the respective time period, are compared. The expected values of the selected accounting indicators are calculated using the least square method.

In order to achieve the objective of the article, the respective obtained ratios are commented on. Namely, ratios of profit, assets and sales as well as ratios of intrinsic value and price, whereas, the intrinsic value is, step by step, calculated using the profit, assets and sales. Overvalued and undervalued stocks are identified as well. Then, the obtained ratios of expected and actual profit and ratios of intrinsic value and average price are commented on. The relationships between the length of the time period included in the linear regression and the difference between the expected and actual profit are suggested. Using stock exchange data it is possible to present the explanatory power of the historical model. Based on the comparison of accuracy of estimates it is clear that the historical model, by all means, belongs to relatively frequently used valuation models. The fundamental analysis assumes the existence of not always correctly valued stocks. This investment analysis is frequently used by investors. It is also apparent that the obtained differences between the expected and actual values, which are presented in tables, may not be regarded as extremely different.

Findings followed from the empirical analysis relate to measured differences between intrinsic values and prices. Many accounting indicators from financial statements can be used to stock valuation, in general. Based on founded profits ratios, assets ratios and sales ratios, intrinsic value and price ratios using various data, the progress of corresponding indicators of companies is relatively stable in time by most of companies. The differences between expected and actual indicators are not diametrically diverse. Mostly, the older data within the linear regression, the higher difference between expected and actual indicators. Despite evident volatility of accounting indicators in time, it is clear that trend of accounting indicator in the past in most cases continues in 2010. So that, no extreme deviations were founded. The longer the time interval included in the linear regression, the less the difference between the expected and actual profit. Next important finding is that it is very easy to apply this, as it was shown, relatively reliable method in the practice, mainly because of availability of needed indicators.

\section{References}

1. Brickner, D. R., Brown, C. A., \& Myring, M. (2007). Using Fundamental Analysis of Financial Information to Explain Unexpected Market Behaviour. Global Business and Economics Review, 9 (4), 366-380. doi: 10.1504/GBER.2007.015100

2. Brown, K. C., \& Reilly, F. K. (2009). Analysis of Investments and Management of Portfolios. Florence: Cengage Learning. 
3. Chisholm, A. M. (2009). An Introduction to International Capital Markets. West Sussex: John Wiley \& Sons.

4. Elleuch, J. (2009). Fundamental Analysis Strategy and the Prediction of Stock Returns. International Research Journal of Finance and Economics, 4 (30), 95-107.

5. Gottwald, R. (2011). Contributions of Fundamental Analysis Within the Framework of Financial Markets Analysis. FIN STAR NET, 2 (1), 1-6.

6. Halsey, R. F. (2000). Using the Residual-Income Stock Price Valuation Model to Teach and Learn Ratio Analysis. Retrieved from http://papers.ssrn.com/sol3/papers.cfm?abstract_id=256595.

7. Little, K. (2012). Tools of Fundamental Analysis. Retrieved from http://stocks.about.com/od/ evaluatingstocks/a/Fundanatools1.htm.

8. Meluzín, T., \& Zinecker, M. (2011). Initial Public Offerings: The Relevance of the Market Timing Hypothesis Under Conditions of the Czech Capital Market. Journal of Competitiveness, 3 (4), 121-137.

9. Mingzhe, Y. (2008). A New Approach to Stock Valuation: Continuous Time Abnormal Earnings Model. Retrieved from http://papers.ssrn.com/sol3/papers.cfm?abstract_id=1302242.

10. Patria Online, a.s. (2012). Patria Online, a.s. Retrieved from http://www.patria.cz/.

11. Thompson, R., Beatty, R., \& Riffe, S. (2001). Log-Linear Stock Valuation Based on Accounting Information. Retrieved from http://papers.ssrn.com/sol3/papers.cfm?abstract_id=311079.

12. Veselá, J. (2003). Analýzy trbu cenných papiru. II. Dí: Fundamentálni analýra. Praha: Nakladatelství Oeconomica.

13. Welc, J. (2010). The Effectiveness of Fundamentally-Adjusted Price-to Sales Multiple in Stock Valuation: The Case of Warsaw Stock Exchange. Retrieved from http://papers.ssrn.com/sol3/papers. cfm?abstract_id=1534868.

14. Yao, Y. (2004). Stock Valuation: The Case of Goldman Sachs. Retrieved from http://papers.ssrn. com/sol3/papers.cfm?abstract_id=577841.

15. Zhong, M., Darrat, A. F., \& Anderson, D. C. (2003). Do US Stock Prices Deviate from their Fundamental Values? Some New Evidence. Journal of Banking \& Finance, 27 (4), 673-697. doi: 10.1016/S0378-4266(01)00259-X

\section{Contact information}

Ing. Mgr. Radim Gottwald

Mendel University in Brno, Faculty of Business and Economics

Zemédèlská 1, 61300 Brno

Tel: +420 545132436

E-mail:radim.gottwald@mendelu.cz.

JEL Classification: G12 